\title{
MINERALOGY OF STREAM SEDIMENTS IN THE GABAL KAB-AMIRI AREA, CENTRAL EASTERN DESERT, EGYPT
}

\author{
Mohamed A. Wetait ${ }^{(2)}$, Ahmed F. El Hadary ${ }^{(1)}$, Ahmed A. Khamies ${ }^{(1)}$, Basem A. Zoheir ${ }^{(2)}$ \\ and Sameh M. Elalfi ${ }^{(1)}$. \\ ${ }^{(1)}$ Nuclear Materials Authority, Cairo ${ }^{(2)}$ Faculty of science, Banha
}

\begin{abstract}
This study provides an information about the heavy mineral composition of stream sediments of Wadi Kab - Amiri, Wadi Kab Um El Abas and Wadi El Saqia in the central Eastern Desert of Egypt. Geological and mineralogical investigations reveal the significant potential of the stream sediments in all the wadis for radioactive anomalies. Mineralogy of the heavy mineral separates includs variable contents of rare metal-, Th- and U-bearing minerals. Monazite, thorite and allanite are recorded in addition to several Nb-Ta-bearing phasess. Electron microprobe and EDX analyses constrain on the variable contents of Th and $U$ in most heavy minerals under investigation. Considering the proximal radiometric anomalies and similar mineralogical composition of the KabAmiriintrusion and the more significant episyenitemass, it is concluded that the investigated stream sediments are endogenic sediments with inherited radiogenic and mineral budget.
\end{abstract}

Keywords:KabAmiri area, Stream sediments, heavy minerals, Th- and U-bearing minerals.

\section{INTRODICTION}

Gabal Kab-Amiri (KA) area is located in the Central Eastern Desert (CED), about $85 \mathrm{~km}$ west of the Red Sea coast, some $29 \mathrm{~km}$ south of the Qena-Safaga asphaltic road. It lies between latitudes $26^{\circ} 17^{\prime} 10^{\prime \prime}$ and $26^{\circ} 25^{\prime} 00^{\prime \prime} \mathrm{N}$ and longitudes $33^{\circ} 31^{\prime} 48^{\prime \prime}$ and $33^{\circ} 38^{\prime} 40^{\prime \prime} \mathrm{E}$. The area is covered by serpentinite, undifferentiated volcanogenic metasediments, metabasalt, syn-orogenic granite (granodiorite), post-orogenic granite (i.e., biotite granite,two mica granite), episyenitized granite, and dykes (aplites\& basalt), in addition to wadi stream sediments. The study area is traversed by Wadi Kab - Amiri (KA) and Wadi Kab Um ElAbas (KU). The two wadis poured their weathered product inWadi El Saqia (ES) which runs to the east (Fig. 1).

Hydrothermal alterations manifested by disseminated and massive hematite and carbonate are reported in the exposure of Gabal Kab Amiri granite (Hayashi, 1973) and Leroy (1978). El Kassas (1974) stated that Gabal Kab Amiri granite is homogenous and its inner zone possess radioactivity higher than its outer zone, where some anomalies were located. The most significant mineralogical and chemical changes of the mineralized altered rocks are the dissolution of quartz $\left(\mathrm{SiO}_{2}\right.$ decreases from $73.69 \%$ in the fresh parts to $50.40 \%$ in the altered parts) and the in- crease of $\mathrm{CaO}$ from 1.05 to $9.27 \%$ due to the precipitation of calcite in the vesicles left after removal of silica(Ammar, 1993). Spectrometric and mineralogical investigations of KabAmiri were done by Abdel Meguid et al. (2003) and the drilling results, (down to $140 \mathrm{~m}$ ), indicate the continuation of themineralizations and is still in the oxidation zone.Also, Gaafar et al., (2010) studied the uranium potentiality of the Wadi Kab Amiri area.Structurally, the episyenitized muscovite granite of Kab-Amiri area was exposed along the ENE-WSW trending axial plane foliation of the secondgeneration folds (F2), intruding deformed volcano-sedimentary rocks in the area (Ali et al., 2008).

\section{GEOLOGICAL SETTING}

The basement rocks of the study area are represented by serpentinite, undifferentiated volcanogenic metasediments, metabasalt, and various types of granitic rocks cut by aplitic and basaltic dykes trending in different directions (Fig. 2). Small body ofepisyentitizedgranite is exposed in the southern part of the study area.

Serpentinite rocks occur as isolated small masses, forming elongated bodies extending generally of E-W direction southwest and southeast of Gabal Kab-Amiri. These rocks are invaded byvolcanogenic 


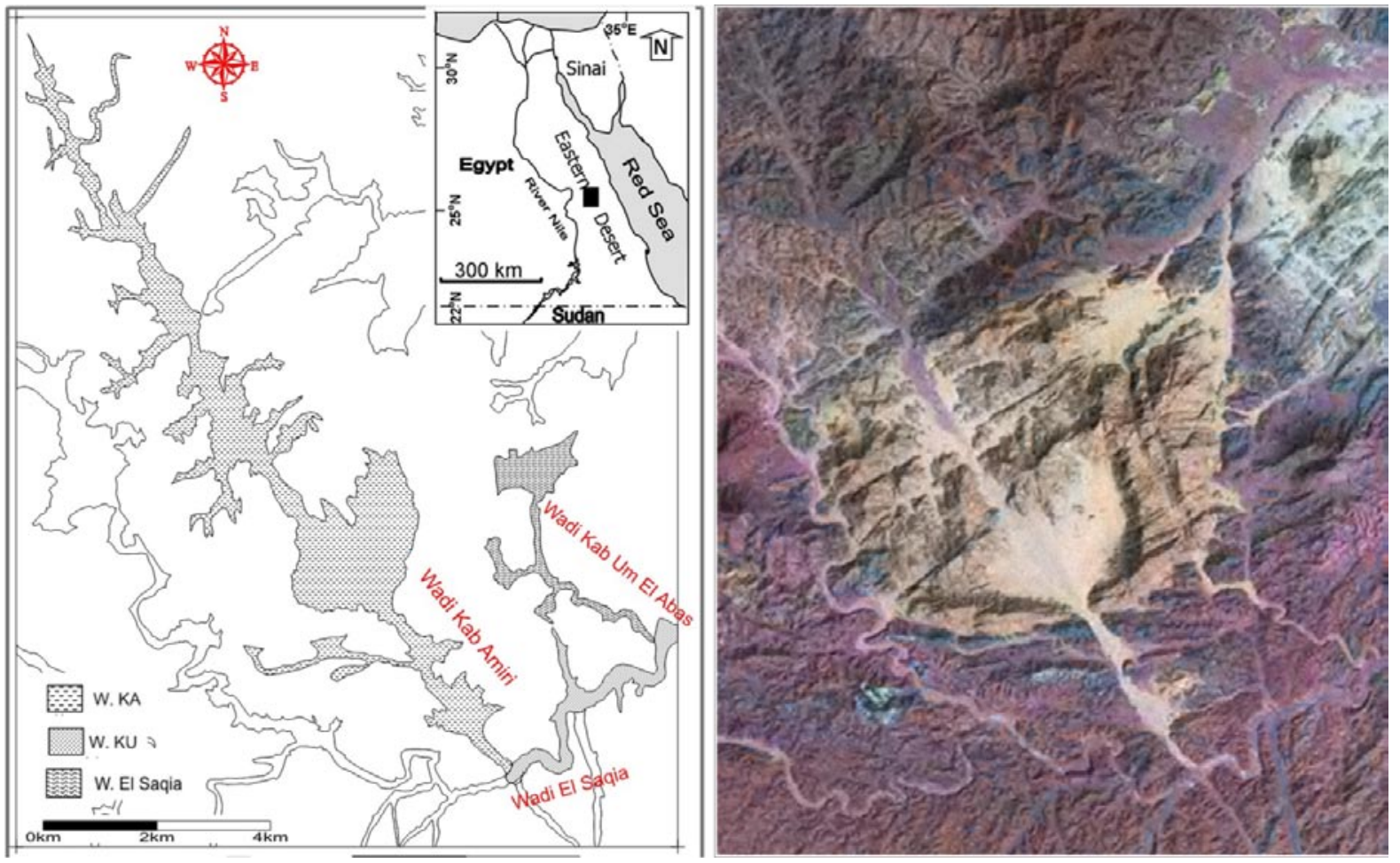

Fig. (1): a) A sketch map of the main wadis and location map of the area.

b) ASTER (731) image of the Gabal Kab- Amiri area.
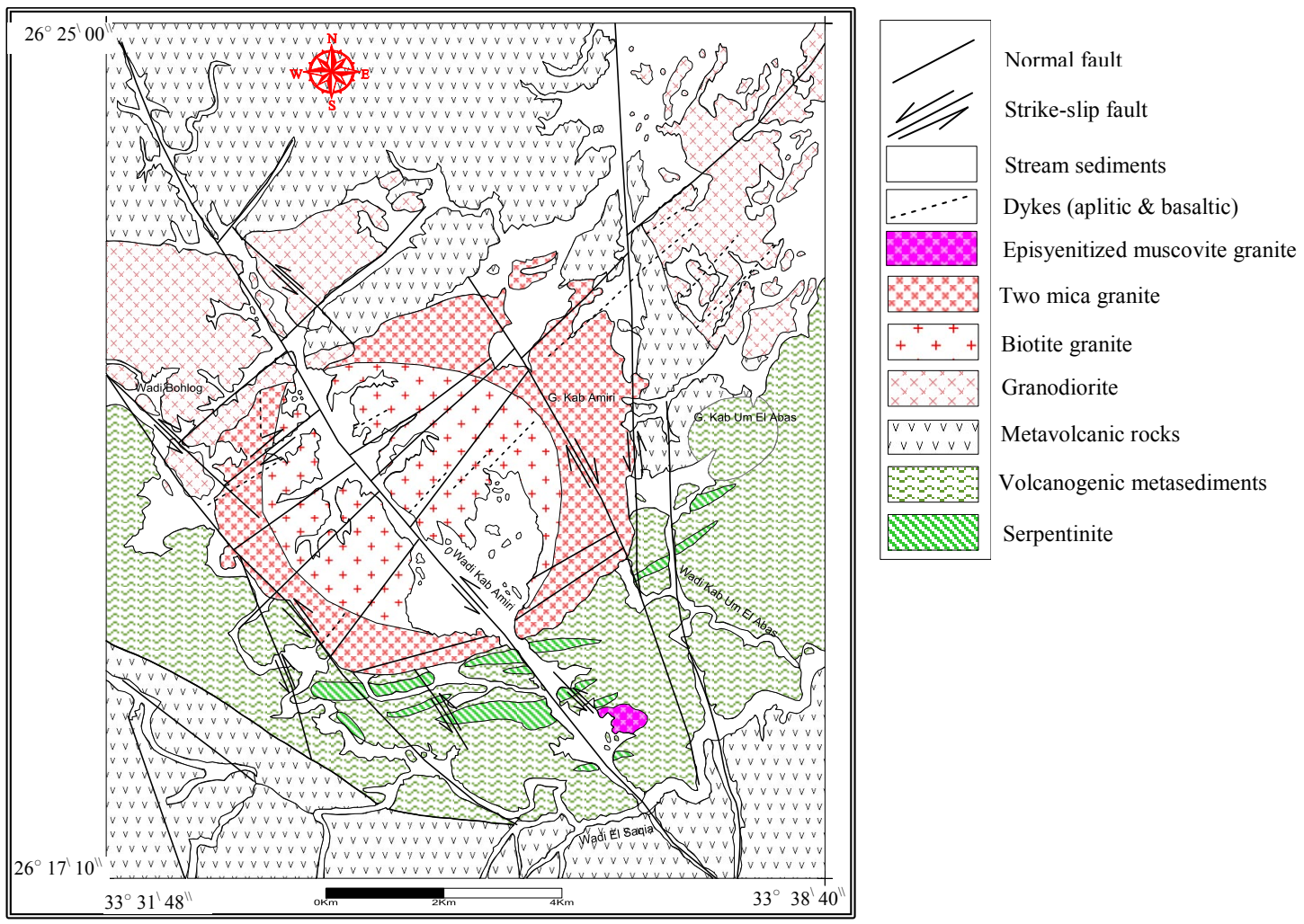

Fig. (2) Geological map of the Kab -Amiri area, Central Eastern Desert (modified after Ali et al. 2008) . 
metasediments (Fig. 3a). The serpentiniterocks contain some large lenses (2-3 m-long) of variably oxidized chromite.

The volcanogenic metasediments form a curvilinear belt surrounding the eastern and southern parts of Kab- Amiri granite. The contacts with the metavolcanics rocks are generally structurally and intrusive contacts. These rocks show mesoscopic, minor folding, and well developed schistosity (Fig. 3b). They are cut by the Kab-Amiri granite, episyenitized granite and quartz veins.

The metavolcanic rocks mainly basic in composition fresh and altered metabasalt. These rocks occupied the southern and northern parts of the mapped area besides small outcrop in the north eastern and western parts of Gabal KabAmiri. The contacts between the metavolcanics and themetasedimentsare structurally contacts and with Kab- Amiri granites are structurally and intrusive contacts They are intruded by granodiorites and two mica granites (Fig. 2), and show sharp contacts (Fig. 3c).
Granodioritesare exposed in north eastern and western parts of Gabal Kab-Amiri, forming a low to moderate relief terrain. These rocks form irregular masses intruding the metavolcanic rocks. They are coarse grained greyish rocks characterized by the presence of many xenoliths from the older rocks (Fig. 3d).

Biotite and two mica granites form the most prominent topographic features of the study area. The granites of Kab - Amiri is oval shape body having a diameter of about 6 to $8 \mathrm{Km}$ cross cut by aNW-SE relatively major wadi trending. they intrude the Serpentinites rocks and metasedimentary rocks. These rocks are composed of two concentric zones (Fig. 3e). The outer zone is represented by fine grained two mica granite with accessory garnet and fluorite showing pink color which is higher relief than the inner one, forming conspicuous peaks, $881 \mathrm{~m}, 916$ and $952 \mathrm{~m}$ above sea level. The highest mountain peak is known as Gabal Kab-Amiri. The inner zone is represented by medium to coarse grained biotite granite with accessory muscovite, allanite and fluorite ex-

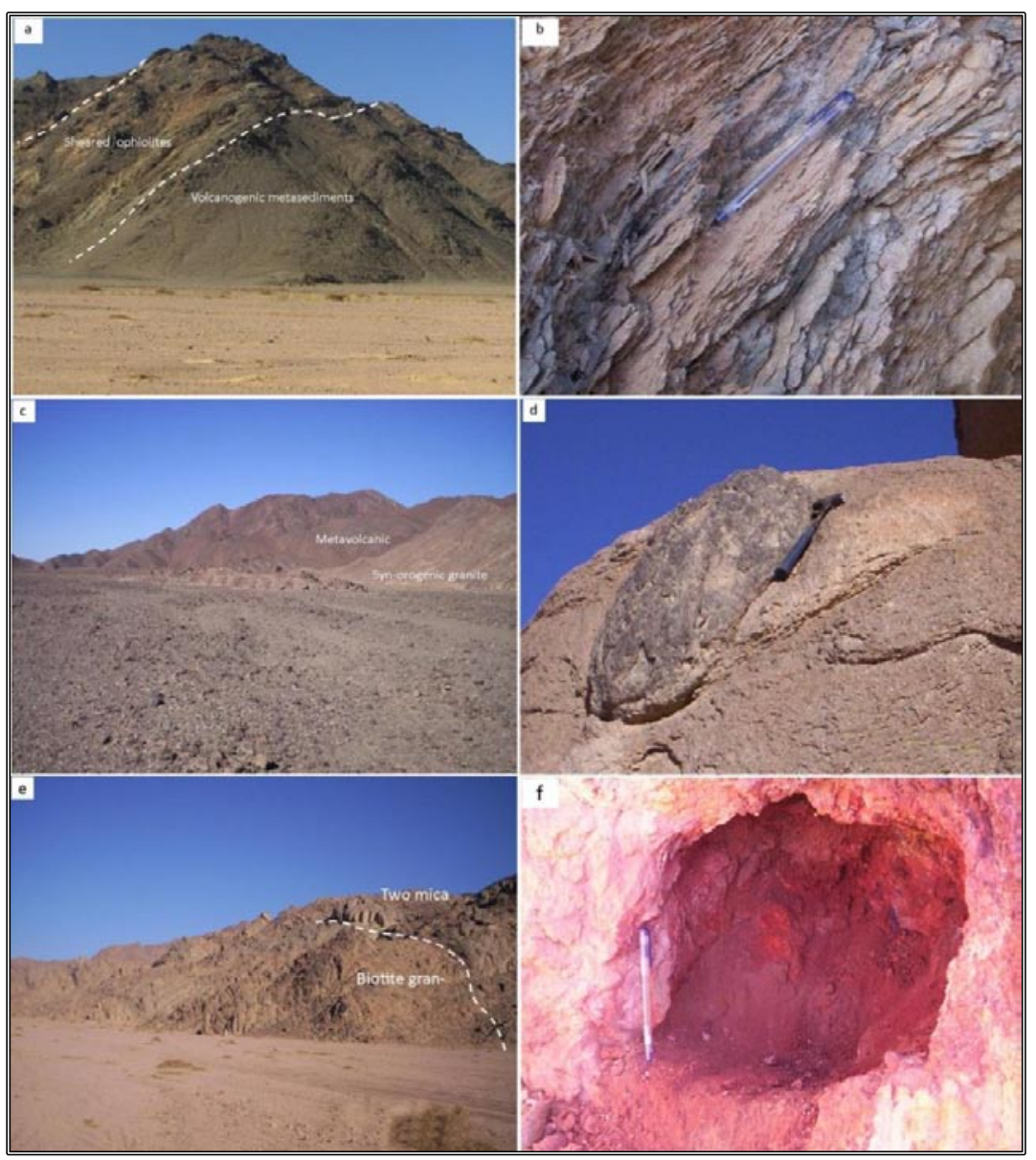

Fig. 3a) Sheared ophiolitic rocks invaded by volcanogenic metasediments south Kab-Amiri peak, photo looking NE, b) Schistosity of volcanogenic metasediment, c)Sharp contact between syn-orogenic granite and metavolcanic, looking northern east, d)Xenoliths of metavolcanic in syn-orogenic granite, looking west, e) Graditional contact between biotite granite (the inner zone) and two mica granite (the outer zone), looking east and f) Hematitization of episyenite. 
hibiting whitish pink color and show low relief. Along the contact between the two mica granite and biotite granite zones of Kab-Amiri granites as well as the contact between the two mica granite and the volcanogenic metasediments country rocksseveral pegmatite bodies and plugs are recorded. The higher radiometric anomaly recorded in the pegmatite is restricted between the inner and the outer zone on the western side of Gabal Kab-Amiri.

Episyenitized muscovite granite occur as a small body of about $0.5 \mathrm{~km}$ in diameterand at 1.5 $\mathrm{km}$ from the south eastern part of Kab Amiri granitic rocks. This body intrudes the volcanogenic metasediments and characterized by medium grained and pink in color. The high peaks within the episyenite formed the unaltered areas. The body is elongated in the E-W direction showing moderate relief, it is highly faulted and fractured in NW, NE and E-W trends. Episyenitization has likely been controlled by the intensity of microfracturing, which enabled percolation of the hydrothermal fluids. The granitic body shows episyenitization as well as other types of alterations such as hematitization and (Fig. 3f), carbonitization (e.g., Ali et al., 2008).

The Kab-Amiri biotite granites are dissected by many basic dykes and quartz veins and pegmatite, varying in composition and trends. The acidic dikes strike mainly in N-S direction, while the basic ones strike in NE-SW direction. Veins and lensoid-shape bodies of pegmatites are observed striking in N-S and NE-SW directions.

The stream sediments in the study area are distributed where wide valleys (Wadis) cut across the mountainous blocks, mainly in Wadi Kab-Amiri, Wadi Kab Um El Abas, and Wadi El-Saqia. Wadi Kab Amiri occupies large part in the study area, it drains from north west to south east direction, with about $15.6 \mathrm{~km}$ length, and width ranging from 180 to $1363 \mathrm{~m}$ in width.

\section{MATERIALS AND METHODS}

In the present study, the samples were collected for the detailed laboratory investigations. Therefore, forty three (43) samples from Wadi Kab-Amiri, five (5) samples from Wadi Kab Um El Abas and six (6) samples from Wadi El
Saqia were collected (Fig. 4). The grain size analysis were made on all the previous collected samples. The mineralogical studies were conducted on twenty eight samples selected from the all collected samples of the area.twenty two samples from Wadi Kab-Amiri, three samples from Wadi Kab Um El Abas, three samples from Wadi El Saqia. Heavy fractions were separated from thesesamples using the conventional bromoform separation technique. Both heavy and light fractions were dried and weighted. Magnetite was separated from the heavy fractions using a small hand magnet with suitable strength. The percentage of light, heavy bromoform and magnetite were calculated and tabulated in Table (1). The light fractions were discarded due to the lack of economic importance.

The magnetite free heavy fractions were magnetically fractionated using the laboratory Frantz Isodynamic Separator at side slope of $5^{\circ}$, forward slope of $20^{\circ}$ (e.g., Flinter,1955). The separation was done at magnetic field $0.2 \mathrm{~A}, 0.5 \mathrm{~A}, 1.0 \mathrm{~A}$, $1.5 \mathrm{~A}$ and the rest of sample consider $1.5 \mathrm{~A}$ nonmagnetic fraction. Hence, five subfractions were obtained with different magnetic susceptibilities. This step will carried out on some selected sam-

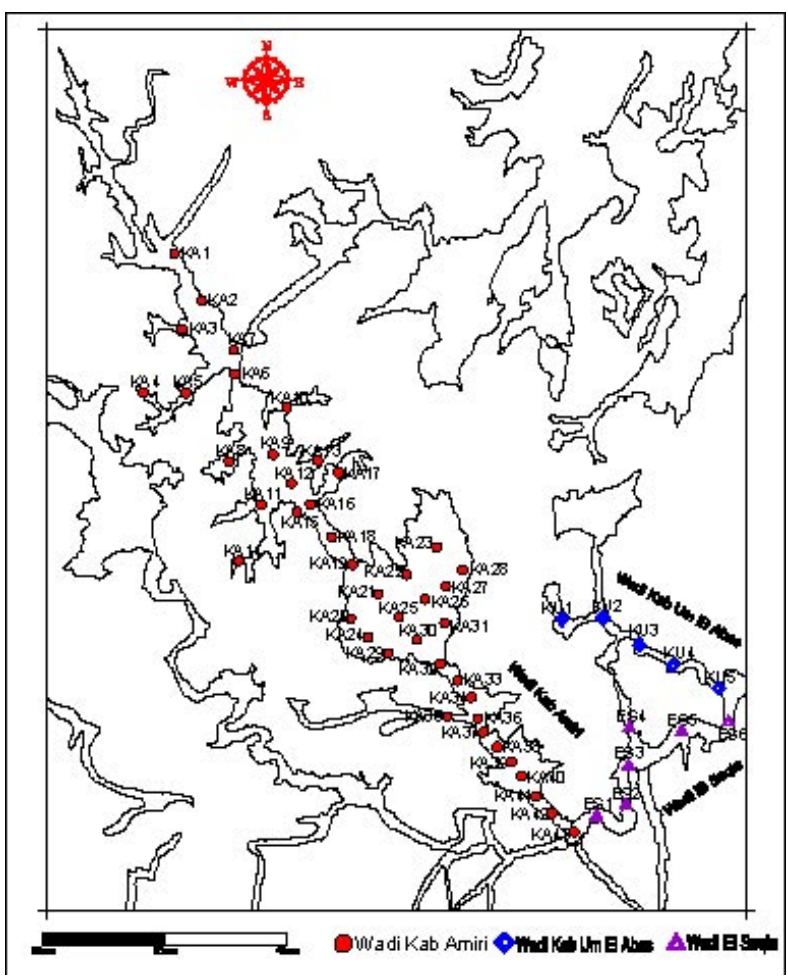

Fig. (4) Sample locations of the collected stream sediments from the study area 
Mineralogy of stream sediments in the Gabal Kab-Amiri area

ples. The obtained sub-fractions were subjected to microscopic examinations using a binocular microscope.

Table (1) Percentages of light, heavy bromoform and magnetite of Wadi Kab-Amiri, Wadi Kab Um El Abas, Wadi El Saqia, of hard rock samples.

\begin{tabular}{|c|c|c|c|c|}
\hline & S. No. & L.Br. \% & H.Br. \% & Mg. \% \\
\hline \multirow{22}{*}{ 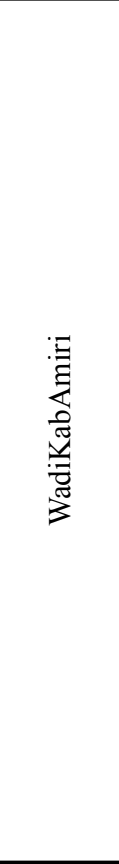 } & KA1 & 79.38 & 20.05 & 0.57 \\
\hline & KA3 & 94.68 & 5.14 & 0.17 \\
\hline & KA6 & 88.13 & 11.01 & 0.86 \\
\hline & KA8 & 95.83 & 3.64 & 0.53 \\
\hline & KA10 & 92.77 & 6.40 & 0.84 \\
\hline & KA12 & 96.69 & 2.96 & 0.35 \\
\hline & KA14 & 95.62 & 3.98 & 0.40 \\
\hline & KA17 & 97.09 & 2.45 & 0.46 \\
\hline & KA19 & 93.39 & 6.03 & 0.59 \\
\hline & KA20 & 97.97 & 1.81 & 0.21 \\
\hline & KA21 & 92.83 & 6.42 & 0.75 \\
\hline & KA22 & 95.56 & 3.67 & 0.77 \\
\hline & KA23 & 98.32 & 1.53 & 0.15 \\
\hline & KA24 & 97.36 & 2.51 & 0.13 \\
\hline & KA26 & 97.98 & 1.73 & 0.30 \\
\hline & KA27 & 98.46 & 1.31 & 0.23 \\
\hline & KA30 & 96.83 & 2.93 & 0.24 \\
\hline & KA32 & 95.74 & 3.82 & 0.45 \\
\hline & KA34 & 95.56 & 4.02 & 0.42 \\
\hline & KA36 & 76.95 & 17.47 & 5.58 \\
\hline & KA40 & 94.05 & 5.24 & 0.71 \\
\hline & KA43 & 85.97 & 13.50 & 0.53 \\
\hline \multirow{3}{*}{ 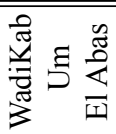 } & KU1 & 94.35 & 4.76 & 0.89 \\
\hline & KU3 & 92.21 & 7.44 & 0.35 \\
\hline & KU5 & 86.72 & 12.83 & 0.45 \\
\hline \multirow{3}{*}{ 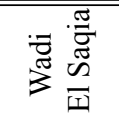 } & $\overline{\text { ES1 }}$ & 79.50 & 20.14 & $\overline{0.36}$ \\
\hline & ES3 & 87.44 & 12.13 & 0.42 \\
\hline & ES5 & 85.47 & 14.09 & 0.44 \\
\hline
\end{tabular}

$\mathrm{L} . \mathrm{Br}=$ light bromoform, $\mathrm{H} . \mathrm{Br}=$ heavy bromoform fraction, Mgt $=$ magnetite

\section{Mineralogy of the heavy fractions}

The different recorded predominant heavy minerals assemblages in the stream sediment samples can be classified into two main groups as according to Folk (1980), the opaque minerals group and the non-opaque minerals group. The opaque minerals group are represented by magnetite, ilmenite, hematite\&geothite, leucoxene, columbite-tantalite series, thorite and allanite minerals. The non-opaque minerals are represented by zircon, rutile, garnet, titanite (sphene), apatite, epidote, monazite, biotite and green silicates group (amphibole, pyroxene). The percentage of each mineral were calculated to the total heavy fractions and tabulated in Table (2).
The following is a brief description of some heavy minerals in the studied samples and their percentage related to the total heavy minerals:

\section{A- Opaque minerals}

Magnetite displays deep reddish brown to black color, with metallic to dull luster and recorded in all samples. It occurs as large black cubic crystals with well-developed angular facets (Fig. 5a), or as fine octahedron crystals. Wadi Kab-Amiri displays magnetite content ranging from $0.128 \%$ to $5.576 \%$ with an average of about $0.692 \%$, while, at Wadi Kab Um El Abasranges from $0.350 \%$ to $.891 \%$ with an average of about $0.563 \%$, and atWadi El Saqia ranges from $0.358 \%$ to $0.442 \%$ with an average of about $0.408 \%$.

Ilmeniteis reportedin all samples as ironblack crystals with metallic luster. It occurs as prismatic, tabulated, and angular to subangular grains. It is more abundant in the finer sand size than in the medium sand size. Wadi Kab-Amiri display ilmenite content ranging from $0.109 \%$ to $3.639 \%$ with an average of about $0.776 \%$, while, at Wadi Kab Um El Abasranges from 1.104\% to $2.614 \%$ with an average of about $1.729 \%$ and atWadi El Saqia ranges from $0.693 \%$ to $1.429 \%$ with an average of about $1.057 \%$.

Hematite \& Geothite recorded in all samples and occur as reddish brown to blackish brown crystals, showing dull earthy luster. Some altered hematite grains with yellowish uranium rims are locally observed (Fig. 5b). Wadi Kab-Amiri display hematite content ranging from $0.004 \%$ to $0.167 \%$ with an average of about $0.040 \%$, while, atWadi Kab Um El Abas ranges from $0.065 \%$ to $0.183 \%$ with an average of about $0.118 \%$ and at Wadi El Saqia ranges from $0.065 \%$ to $0.333 \%$ with an average of about $0.177 \%$.

Columbite and tantalite recorded in the stream sediments adjacent the episyenitized granite (episyentite) of Gabal Kab-Amiri area. Both columbite and tantalite were recorded as small black, flattened, short prismatic crystal habit with smooth surface. The minerals have semi-resinous luster under the binocular. Wadi Kab-Amiri display Tantalite-Columbite series content ranging from $0.001 \%$ to $0.010 \%$ with 
Table (2) The percentage of total heavy minerals of Wadi Kab - Amiri, Wadi Kab Um El Abas and Wadi El Saqia.

\begin{tabular}{|c|c|c|c|c|c|c|c|c|c|c|c|c|c|c|c|c|}
\hline & S. No. & Mgt.\% & Ilm.\% & $\mathrm{He} . \%$ & Leuco.\% & Rut.\% & Zr.\% & Gar.\% & Sph.\% & Bio.\% & Apat.\% & G. S. $\%$ & Mon.\% & Alla.\% & Col.\% & Tho.\% \\
\hline \multirow{25}{*}{ 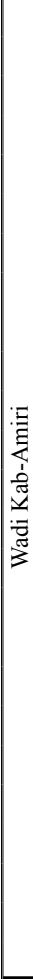 } & KA1 & 0.573 & 0.792 & 0.042 & 0.609 & 0.234 & 1.364 & Nil & Nil & 0.056 & Nil & 16.950 & Nil & Nil & Nil & Nil \\
\hline & KA3 & 0.173 & 0.193 & 0.004 & 0.155 & 0.110 & 0.693 & Nil & Nil & 0.017 & Nil & 3.971 & Nil & Nil & Nil & Nil \\
\hline & KA6 & 0.861 & 0.950 & 0.068 & 0.520 & 0.470 & 0.880 & Nil & 0.096 & 0.058 & Nil & 7.968 & Nil & Nil & Nil & Nil \\
\hline & KA8 & 0.528 & 0.269 & 0.010 & 0.138 & 0.132 & 0.678 & Nil & 0.022 & 0.009 & Nil & 2.381 & Nil & Nil & Nil & Nil \\
\hline & KA10 & 0.836 & 0.429 & 0.006 & 0.142 & 0.227 & 0.962 & Nil & 0.042 & 0.026 & Nil & 4.563 & Nil & Nil & Nil & Nil \\
\hline & KA12 & 0.350 & 0.211 & 0.005 & 0.077 & 0.071 & 0.674 & Nil & 0.021 & 0.010 & Nil & 1.887 & Nil & Nil & Nil & Nil \\
\hline & KA14 & 0.399 & 0.293 & 0.004 & 0.122 & 0.101 & 0.534 & Nil & 0.028 & 0.017 & Nil & 2.878 & Nil & Nil & Nil & Nil \\
\hline & KA17 & 0.460 & 1.049 & 0.033 & 0.163 & 0.037 & 0.277 & 0.037 & 0.021 & 0.051 & Nil & 0.783 & Nil & Nil & Nil & Nil \\
\hline & KA19 & 0.585 & 0.426 & 0.068 & 0.188 & 0.241 & 0.825 & 0.169 & 0.034 & 0.113 & 0.105 & 3.822 & 0.004 & 0.006 & 0.010 & 0.017 \\
\hline & KA20 & 0.215 & 0.288 & 0.009 & 0.042 & 0.068 & 0.369 & 0.042 & 0.009 & 0.021 & 0.025 & 0.935 & 0.001 & 0.001 & 0.001 & 0.003 \\
\hline & KA21 & 0.746 & 0.993 & 0.039 & 0.114 & 0.291 & 0.829 & 0.220 & 0.042 & 0.074 & 0.079 & 3.649 & 0.004 & 0.006 & 0.010 & 0.020 \\
\hline & KA22 & 0.774 & 0.509 & 0.017 & 0.138 & 0.145 & 0.775 & 0.101 & 0.021 & 0.097 & 0.061 & 1.789 & 0.002 & Nil & 0.005 & 0.007 \\
\hline & KA23 & 0.147 & 0.599 & 0.018 & 0.130 & 0.116 & 0.153 & 0.075 & Nil & 0.167 & 0.067 & 1.552 & 0.004 & 0.003 & 0.008 & 0.004 \\
\hline & KA24 & 0.128 & 0.370 & 0.015 & 0.109 & 0.102 & 0.446 & 0.068 & 0.012 & 0.128 & 0.050 & 1.174 & 0.002 & 0.001 & 0.002 & 0.007 \\
\hline & KA26 & 0.297 & 0.269 & 0.013 & 0.070 & 0.083 & 0.356 & 0.042 & 0.010 & 0.089 & 0.032 & 0.756 & Nil & Nil & 0.002 & 0.007 \\
\hline & KA27 & 0.228 & 0.109 & 0.009 & 0.054 & 0.058 & 0.132 & 0.035 & 0.007 & 0.078 & 0.030 & 0.794 & 0.001 & 0.001 & 0.001 & 0.004 \\
\hline & KA30 & 0.240 & 0.136 & 0.035 & 0.095 & 0.156 & 0.384 & 0.084 & 0.016 & 0.138 & 0.049 & 1.815 & 0.004 & 0.003 & 0.006 & 0.005 \\
\hline & KA32 & 0.447 & 0.435 & 0.054 & 0.158 & 0.201 & 0.568 & 0.111 & 0.018 & 0.134 & 0.051 & 2.087 & Nil & Nil & $\mathrm{Nil}$ & Nil \\
\hline & KA34 & 0.415 & 0.775 & 0.047 & 0.202 & 0.118 & 0.238 & 0.148 & 0.025 & 0.105 & 0.054 & 2.310 & Nil & Nil & Nil & Nil \\
\hline & KA36 & 5.576 & 3.639 & 0.115 & 0.917 & 0.341 & 3.555 & 0.419 & 0.088 & 0.127 & 0.135 & 8.136 & Nil & Nil & Nil & Nil \\
\hline & KA40 & 0.708 & 1.004 & 0.095 & 0.160 & 0.149 & 0.625 & 0.012 & 0.112 & 0.058 & 0.090 & 2.905 & 0.003 & 0.002 & 0.008 & 0.017 \\
\hline & KA43 & 0.529 & 3.327 & 0.167 & 0.414 & 0.303 & 0.947 & 0.068 & 0.117 & 0.223 & 0.224 & 7.712 & Nil & Nil & $\mathrm{Nil}$ & Nil \\
\hline & Min & 0.1280 & 0.1090 & 0.0040 & 0.0420 & 0.0370 & 0.1320 & 0.0120 & 0.0070 & 0.0090 & 0.0250 & 0.7560 & 0.0010 & 0.0010 & 0.0010 & 0.0030 \\
\hline & $\operatorname{Max}$ & 5.5760 & 3.6390 & 0.1670 & 0.9170 & 0.4700 & 3.5550 & 0.4190 & 0.1170 & 0.2230 & 0.2240 & 16.9500 & 0.0040 & 0.0060 & 0.0100 & 0.0200 \\
\hline & Aveg. & 0.6916 & 0.7757 & 0.0397 & 0.2144 & 0.1706 & 0.7393 & 0.1087 & 0.0390 & 0.0816 & 0.0751 & 3.6735 & 0.0028 & 0.0029 & 0.0053 & 0.0091 \\
\hline \multirow{6}{*}{ 变 } & KU1 & 0.891 & 1.104 & 0.065 & 0.663 & 0.030 & 0.551 & 0.431 & 0.469 & Nil & 0.103 & 1.292 & 0.004 & 0.006 & 0.006 & 0.034 \\
\hline & KU3 & 0.350 & 1.469 & 0.107 & 1.031 & 0.032 & 0.657 & 0.490 & 0.664 & Nil & 0.133 & 2.805 & Nil & 0.011 & 0.004 & 0.041 \\
\hline & KU5 & 0.448 & 2.614 & 0.183 & 1.772 & 0.033 & 1.282 & 0.769 & 0.938 & Nil & 0.280 & 4.908 & Nil & 0.018 & 0.007 & 0.026 \\
\hline & Min & 0.3500 & 1.1040 & 0.0650 & 0.6630 & 0.0300 & 0.5510 & 0.4310 & 0.4690 & Nil & 0.1030 & 1.2920 & 0.0040 & 0.0060 & 0.0040 & 0.0260 \\
\hline & $\operatorname{Max}$ & 0.8910 & 2.6140 & 0.1830 & 1.7720 & 0.0330 & 1.2820 & 0.7690 & 0.9380 & Nil & 0.2800 & 4.9080 & 0.0040 & 0.0180 & 0.0070 & 0.0410 \\
\hline & Aveg. & 0.5630 & 1.7290 & 0.1183 & 1.1553 & 0.0317 & 0.8300 & 0.5633 & 0.6903 & Nil & 0.1720 & 3.0017 & 0.0040 & 0.0117 & 0.0057 & 0.0337 \\
\hline \multirow{6}{*}{3} & ES1 & 0.358 & 1.048 & 0.333 & 1.661 & 0.309 & 0.781 & Nil & $\begin{array}{l}0.857 \\
\end{array}$ & 0.038 & 0.357 & 14.766 & Nil & Nil & Nil & Nil \\
\hline & ES3 & 0.424 & 0.693 & 0.065 & 0.684 & 0.085 & 0.628 & $\mathrm{Nil}$ & 0.241 & 0.014 & 0.224 & 9.497 & Nil & Nil & Nil & Nil \\
\hline & ES5 & 0.442 & 1.429 & 0.132 & 0.391 & 0.053 & 0.853 & Nil & 0.424 & 0.023 & 0.313 & 10.474 & Nil & Nil & Nil & Nil \\
\hline & Min & 0.358 & 0.693 & 0.065 & 0.391 & 0.053 & 0.628 & $\mathrm{Nil}$ & 0.241 & 0.014 & 0.224 & 9.497 & Nil & Nil & Nil & Nil \\
\hline & $\operatorname{Max}$ & 0.442 & 1.429 & 0.333 & 1.661 & 0.309 & 0.853 & Nil & 0.857 & 0.038 & 0.357 & 14.766 & Nil & Nil & Nil & Nil \\
\hline & Aveg. & 0.408 & 1.057 & 0.177 & 0.912 & 0.149 & 0.754 & Nil & 0.507 & 0.025 & 0.298 & 11.579 & Nil & $\mathrm{Nil}$ & Nil & Nil \\
\hline
\end{tabular}

S. No.= Sample number, Mgt.=Magnetite, Ilm.=Ilmenite, He.=Hematite, Leuco.=Leocuxene, Rut.=Rutile

Zr.=Zircon, Gar.=Garnet,Sph.=Sphene, Bio.=Biotite, Apat.=Apatite

G.S.=Green Silicates, Mon.=Monazite, Alla.=Allanite,

Col. $=$ Columbite-Tantalite series, Tho. $=$ Thorite.

an average of about $0.005 \%$, while, atWadi Kab Um El Abasranges from $0.004 \%$ to $0.007 \%$ with an average of about $0.006 \%$ and completely absent atWadi El Saqia.

Thorite is observed from sample No. KA19 to KA30 at Wadi Kab-Amiri and in the three samples of Wadi Kab Um El Abas, as black euhedral and subhedral and brown euhedral crystals (Fig. 5c). At Wadi Kab-Amiri, thoriteranging from $0.003 \%$ to $0.020 \%$ with an average of $0.009 \%$ while at Wadi Kab Um El-Abas ranges from $0.026 \%$ to $0.041 \%$ with an average of about $0.034 \%$ and completely absent at Wadi El Saqia. 
Allanite recorded in samples Nos. KA19, 20, 21, 23, 24, 27 and 30 at Wadi Kab-Amiri and in the three samples of Wadi Kab Um El Abas. It shows a translucent brownish black to black euhedral to subhedral crystals with vitreous luster. Allanite contents at Wadi Kab Amiri ranging from $0.001 \%$ to $0.006 \%$, with an average of about $0.003 \%$, while at Wadi Kab Um El-Abasranges from $0.006 \%$ to $0.018 \%$ with an average of about $0.012 \%$, and completely absent at Wadi El Saqia.

\section{B- Non opaque minerals}

Zircon is recorded in all study samples. Wadi Kab-Amiri samples di splay zircon content ranging from $0.132 \%$ to $3.555 \%$ with an average of about $0.739 \%$, while, at Wadi Kab Um El-Abas ranges from $0.551 \%$ to $1.282 \%$ with an average of about $0.830 \%$ and at Wadi El-Saqia ranges from $0.628 \%$ to $0.853 \%$ with an average of about $0.754 \%$. Most of zircon grains are euhedral, bipyramidal, short prismatic to long prismatic. Few grains were recorded in $0.5 \mathrm{~A}$ by the Frantz Isodynamic Separator, likely due to iron inclusions. This type of zircon shows reddish black to black color (Fig. 5d). Some grains separated at 1.0 A have red to reddish yellow to yellow and muddy color.

Apatiteis abundant in stream sediments of the study area. It occurs as large colorless crystals with indication of some inclusions inside the grains. It forms small prismatic crystals with vitreous luster or short prismatic yellow grains (Fig. 5e). Apatite was recorded from the samples No. KA19 to KA30 and its content at Wadi KabAmiri ranging from $0.025 \%$ to $0.224 \%$ with an average of about $0.075 \%$, while, at Wadi Kab Um El Abas ranges from $0.103 \%$ to $0.280 \%$ with an average of about $0.172 \%$, and at Wadi El Saqia ranges from $0.224 \%$ to $0.357 \%$ with an average of about $0.298 \%$.

Rutile is a common accessory mineral in stream sediments and occurs in all studied samples. Its color ranges from yellowish brown to reddish brown. Rutile occurs as prismatic, elongated tabular or needle-like crystals. At Wadi Kab-Amiri samples, rutile contents ranging from $0.037 \%$ to $0.470 \%$ with an average of about $0.171 \%$, while, at Wadi Kab Um El-Abasranges from $0.030 \%$ to $0.033 \%$ with an average of about $0.032 \%$, and at Wadi El-Saqia it ranges from $0.053 \%$ to $0.309 \%$ with an average of about $0.149 \%$.

Garnet, of euhedral grains are rare but the anhedral grains are common with sharp edges. It is recorded in all samples except KA1 and varies from colorless, rose to red colorwith vitreous luster. At Wadi Kab-Amiri garnet content ranging from $0.012 \%$ to $0.419 \%$ with an average of about $0.109 \%$, while, at Wadi Kab Um El Abasranges from $0.431 \%$ to $0.769 \%$ with an average of about $0.563 \%$ and completely absent at Wadi El Saqia.

Monazite exhibits shape varies from rounded to oval. Its color ranges from honey to reddish brown. It occurs as accessory mineral in fine and very fine sand sizes in most of the investigated samples. Monazite was recorded in samples Nos. KA19, 20, 21, 23, 24, 27 and 30 at Wadi Kab-Amiri and in sample No. KU1 at Wadi Kab Um El-Abas, while completely absent at Wadi El-Saqia. Its content at Wadi Kab-Amiri ranges from $0.001 \%$ to $0.004 \%$ with an average of about $0.003 \%$.

Sphene is more common in stream sediments in the studied area except samples No. KA1, KA3 and KA23. Its color varies from yellowish to brownish yellow with vitreous luster (Fig. 5f). It was recorded from sample No. KA6 from Wadi Kab-Amiri, and at Wadi Kab Um El-Abasand Wadi El-Saqia samples. It constitutes 0.007 to $0.117 \%$, with an average of about $0.039 \%$. at Wadi Kab Um El-Abas samplesranges from 0.469 to $0.938 \%$ with an average of about $0.690 \%$ of the stream and at Wadi ElSaqiaranges from 0.241 to $0.857 \%$ with an average of about $0.509 \%$

Biotite has pale yellow to brown color with vitreous luster and red inclusions and range from transparent to translucent in transmitted light (Fig. 5g). It is commonly occur as lamellar plates without crystal outlines. Cleavage is perfect and giving flexibility and elastic lamellae. Biotite is recorded along Wadi Kab-Amiri and Wadi ElSaqia samples, but completely absent atWadi 
Mohamed A. Wetait, et al.
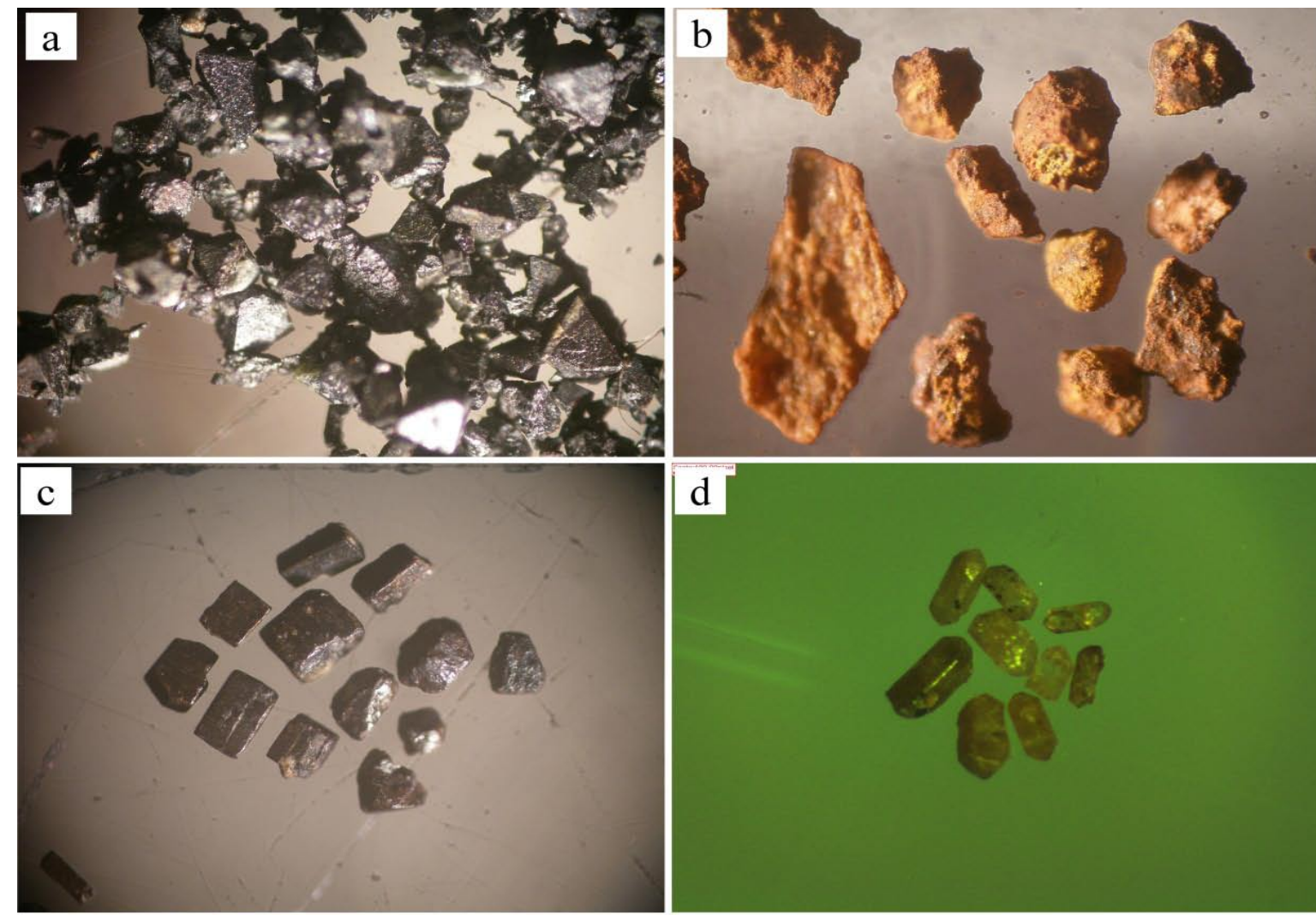

d
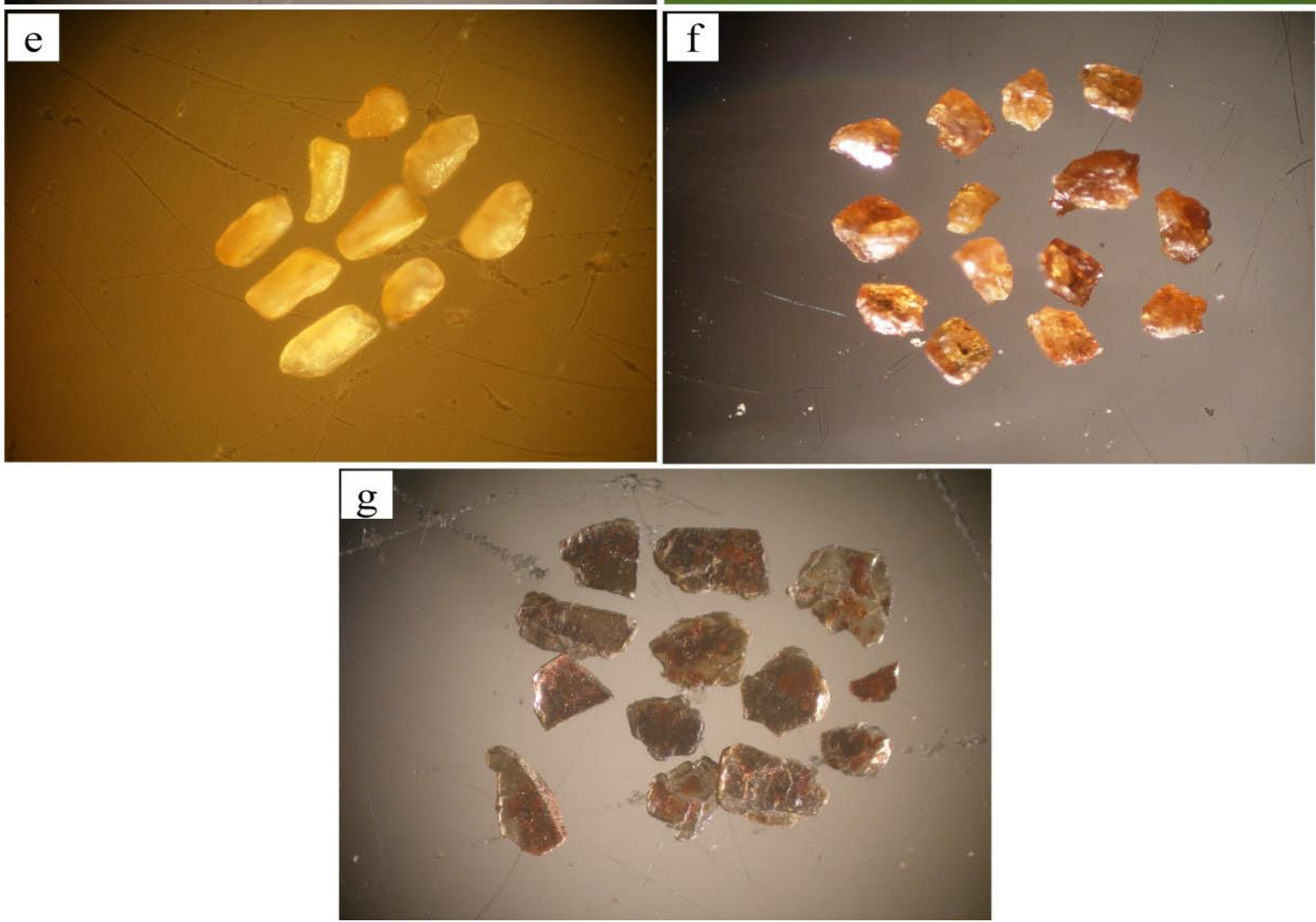

Fig. 5a)Angular to sub angular magnetitegrains (10x), b)Altered hematite grains coated with uranium mineral (yellow spots) (10x), c) Black euhedralt horite grains (10x), d)Yellow zircon (10x), e)Short prismatic yellow apatite grains (10x), f)Brownish yellow sphene (10x) and g)Biotite with red inclusions (10x). 
Mineralogy of stream sediments in the Gabal Kab-Amiri area

Kab Um El-Abas samples. Biotite content ranges from 0.009 to $0.223 \%$ with an average of about $0.082 \%$ at Wadi Kab-Amiri. In Wadi El-Saqiait forms 0.014 to $0.038 \%$, with an average of about $0.025 \%$.

\section{EDX and electron microprobe analysis of Th-, U-, REE-bearing mineral phases}

In order to give some information about the mineral chemistry of the significant heavy minerals of the study stream sediments, some elec-

Table (3) Representative electron probe analysis of thorite crystals from the study area.

\begin{tabular}{|c|c|c|c|}
\hline Oxide /wt\% & 1 & 2 & 3 \\
\hline $\mathrm{SiO}_{2}$ & 16.55 & 15.63 & 14.52 \\
\hline $\mathrm{TiO}_{2}$ & 0.55 & 0.32 & 0.05 \\
\hline $\mathrm{FeO}$ & 3.31 & 1.54 & 2.14 \\
\hline $\mathrm{Y}_{2} \mathrm{O}_{3}$ & 2.32 & 1.87 & 1.94 \\
\hline $\mathrm{Ce} 2 \mathrm{O3}$ & 1.36 & 1.30 & 0.78 \\
\hline $\mathrm{Pr}_{2} \mathrm{O}_{3}$ & 1.93 & 0.51 & 0.85 \\
\hline $\mathrm{Nd}_{2} \mathrm{O}_{3}$ & 1.57 & 1.58 & 0.92 \\
\hline $\mathrm{Ta}_{2} \mathrm{O}_{5}$ & 2.14 & 2.15 & 1.25 \\
\hline $\mathrm{ThO}_{2}$ & 59.66 & 66.17 & 71.20 \\
\hline $\mathrm{UO}_{2}$ & 9.83 & 8.41 & 6.67 \\
\hline Total & 99.22 & 99.48 & 100.32 \\
\hline
\end{tabular}

Table (4) EDX data of thorite and matrix grains in stream sediments of KabAmiri area.

\begin{tabular}{|l|l|l|l|l||}
\hline & \multicolumn{2}{|c|}{ matrix } & \multicolumn{2}{c||}{ thorite } \\
\hline $\mathbf{O}$ & 19.43 & 49.33 & 16.88 & 57.10 \\
\hline $\mathrm{Si}$ & 1.31 & 1.89 & 8.33 & 16.04 \\
\hline $\mathbf{P}$ & 0.00 & 0.00 & 0.50 & 0.88 \\
\hline $\mathbf{C a}$ & 0.17 & 0.17 & 1.51 & 2.04 \\
\hline $\mathbf{S c}$ & 0.35 & 0.32 & 1.23 & 1.48 \\
\hline $\mathbf{T i}$ & 0.33 & 0.28 & 0.42 & 0.47 \\
\hline $\mathbf{M n}$ & 0.49 & 0.36 & 0.42 & 0.41 \\
\hline $\mathbf{F e}$ & 59.04 & 42.95 & 2.77 & 2.68 \\
\hline $\mathbf{Y}$ & 0.43 & 0.20 & 3.31 & 2.01 \\
\hline $\mathbf{N b}$ & 0.40 & 0.17 & 1.83 & 1.07 \\
\hline $\mathbf{S n}$ & 0.67 & 0.23 & 0.00 & 0.00 \\
\hline $\mathbf{C e}$ & 1.12 & 0.33 & 2.80 & 1.08 \\
\hline $\mathbf{P r}$ & 1.53 & 0.44 & 2.45 & 0.94 \\
\hline $\mathbf{N d}$ & 1.28 & 0.36 & 0.00 & 0.00 \\
\hline $\mathbf{T a}$ & 12.54 & 2.82 & 5.78 & 1.73 \\
\hline $\mathbf{T h}$ & 0.57 & 0.10 & 45.73 & 10.67 \\
\hline $\mathbf{U}$ & 0.34 & 0.06 & 6.04 & 1.37 \\
\hline & 100.0 & 100.0 & 100.0 & 100.0 \\
\hline
\end{tabular}

tron probe microanalyses spots have been carried out, and the results are given below.

\section{REE-bearing thorite}

REE-bearing thorite (Th,U,Y,Ta,REE) $\mathrm{SiO}_{4}$ forms subhedral tetragonal crystals with yellowish brown color and vitreous luster under the binocular. In the comprehensive investigation in the backscattered electron imaging, relict of this mineral occur in goethite-like matrix (hydrothorite?) with rhythmic bands with variable $\mathrm{Fe}$ and Th contents (Fig. 6a \& b). Apatite and Ca-Si-P phase occurs as inclusions in goethite-like matrix (Fig. $6 c \& d$ ). The chemical analyses of thorite indicate $\mathrm{Y}$-bearing uranothorite composition where $\mathrm{UO}_{2}$ amounts up to $9.83 \mathrm{wt} \%$, and up to 2.32 wt. $\% \mathrm{Y}_{2} \mathrm{O}_{3}$ Table (3). Thorite inclusions in the goethite-like matrix are common. Worth noting, this matrix is found to be Ta-and REE-bearing Table (4). Traces of Y, Ta and Ce are also detected in the thorite inclusions Table (4).

\section{Monazite}

Monazite and xenotime are the most important REE-bearing phosphates (rare-earth elements) that occur in a wide range of magmatic and metamorphic rocks as an accessory or as rockforming minerals (e.g., Orrisand Grauch, 2002; Dill, 2010). The monazite crystals observed in the separates were generally subhedral, colorless and pitted. Chemical analyses of monazite show typical common contents of REE such as $\mathrm{La}, \mathrm{Ce}, \mathrm{Nd}$ and Sm Table (5). Remarkably high $\mathrm{ThO}_{2}(6.64-8.25 \mathrm{wt} \%)$ may be regarded to fine thorite and xenotime inclusions. Traces of $\mathrm{CaO}$ (up to $3.27 \mathrm{wt} \%$ ) and $\mathrm{Ta}_{2} \mathrm{O}_{5}(1.87 \mathrm{wt} \%$ ), can be attributed to the presence of fine inclusions of apatite and tantalite (Fig. 7a \&b).

\section{Conclusions}

The investigated stream sediments are represented by opaque and non-opaque minerals. The opaque mineralsare represented by magnetite, ilmenite, hematite \&geothite, leucoxene, columbite-Tantalite series, thorite and allanite minerals. The non-opaque minerals are represented by zircon, rutile, garnet, titanite (sphene), apatite, epidote, monazite, biotite and green silicates group (amphibole, pyroxene).The phosphate minerals, i.e., monazite (LREE and Th) and REE 

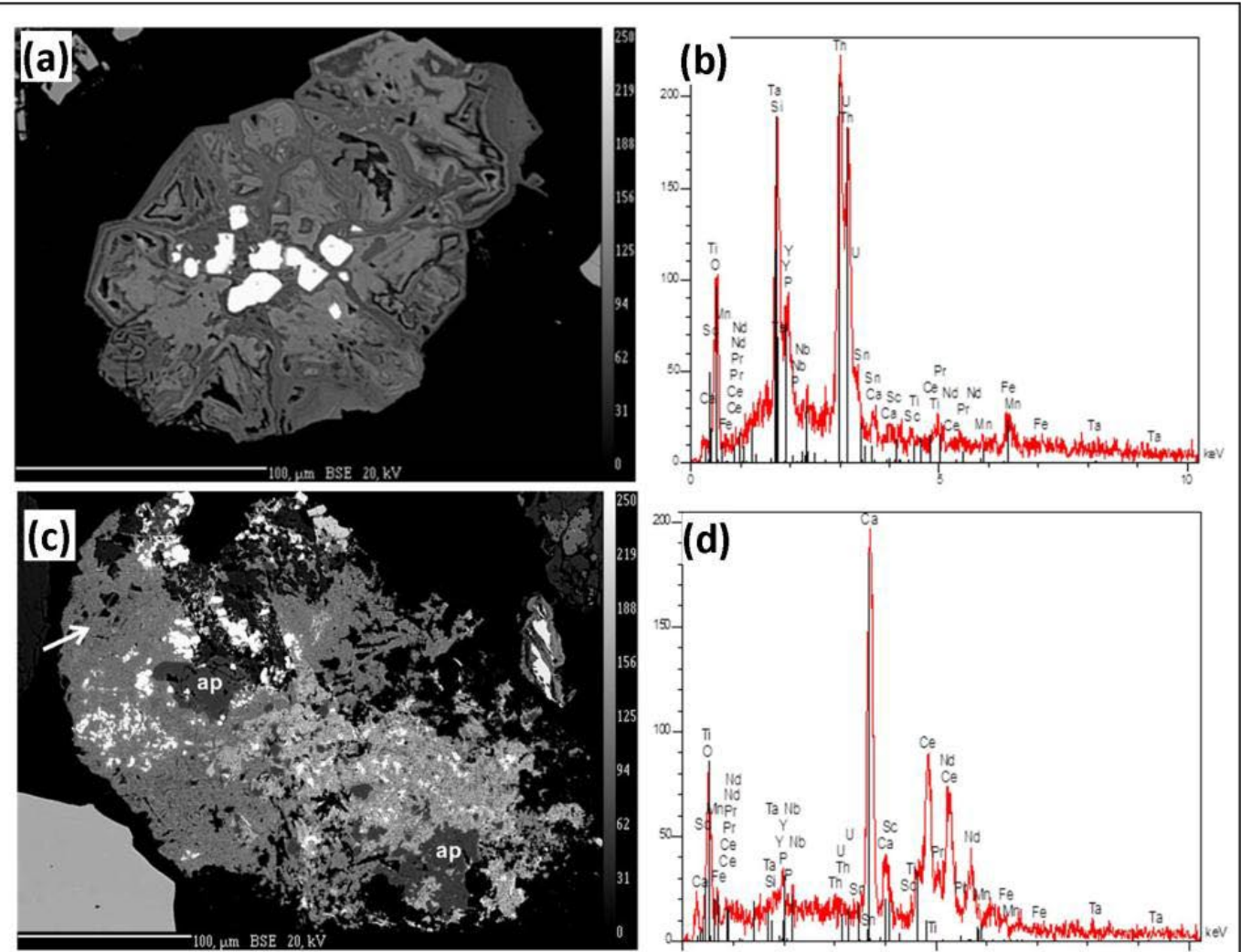

Fig. 6a) Backscattered electron image of bright REE-bearing Th-silicate phase (thorite) in goethite-like matrix, b) Spectra of the main element components showing Th, U, Y and REE peaks along with the $\mathrm{Si}$ and $\mathrm{O}$ ones, c) Bright-white spots: Th-silicate phase,Light-grey matrix: Ca-Si-P phase, White arrow (grey matrix): goethite-like phase, dark grey (ap) = apatite, d) Spectra of the main element components of the matrix showing traces of $\mathrm{Ta}, \mathrm{Th}, \mathrm{U}, \mathrm{Y}$ and REE.

Table (5) Representative electron probe analysis of monazite crystals from Kab Amiri area.

\begin{tabular}{|l|c|c|c|c|c|c|}
\hline & 1 & 2 & 3 & 4 & 5 & 6 \\
\hline $\mathbf{S i O}_{\mathbf{2}}$ & 0.29 & 0.31 & 0.29 & 0.18 & 0.43 & 0.41 \\
\hline $\mathbf{P}_{\mathbf{2}} \mathbf{O}_{\mathbf{5}}$ & 30.27 & 29.98 & 31.31 & 29.74 & 30.58 & 29.05 \\
\hline $\mathbf{C a O}$ & 1.95 & 2.03 & 1.93 & 3.21 & 3.27 & 3.11 \\
\hline $\mathbf{L a}_{\mathbf{2}} \mathbf{O}_{\mathbf{3}}$ & 15.66 & 14.88 & 16.02 & 15.22 & 16.16 & 17.05 \\
\hline $\mathbf{C e}_{\mathbf{2}} \mathbf{O}_{\mathbf{3}}$ & 28.37 & 26.95 & 25.60 & 29.11 & 27.65 & 30.25 \\
\hline $\mathbf{N d}_{\mathbf{2}} \mathbf{O}_{\mathbf{3}}$ & 12.84 & 13.39 & 12.72 & 12.08 & 11.48 & 9.58 \\
\hline $\mathbf{S m}_{\mathbf{2}} \mathbf{O}_{\mathbf{3}}$ & 1.68 & 2.30 & 2.44 & 2.32 & 1.11 & 1.05 \\
\hline $\mathbf{T a}_{\mathbf{2}} \mathbf{O}_{\mathbf{5}}$ & 1.16 & 1.55 & 1.87 & 1.78 & 0.98 & 0.88 \\
\hline $\mathbf{T h O}_{\mathbf{2}}$ & 6.65 & 7.36 & 6.99 & 6.64 & 8.25 & 7.84 \\
\hline $\mathbf{U O}_{\mathbf{2}}$ & 0.12 & 0.21 & 0.20 & 0.10 & 0.23 & 0.13 \\
\hline $\mathbf{T o t a l}_{\mathbf{n}}$ & 98.99 & 98.96 & 99.38 & 100.38 & 100.14 & 99.35 \\
\hline
\end{tabular}

Fig. 7a) Backscattered electron image of monazite (red arrow) crystal severely oxidized and with thorite and xenotime inclusions (yellow arrow) with intergrowths of apatite (white arrow), b) Spectra of the main element components of amonazite crystal.

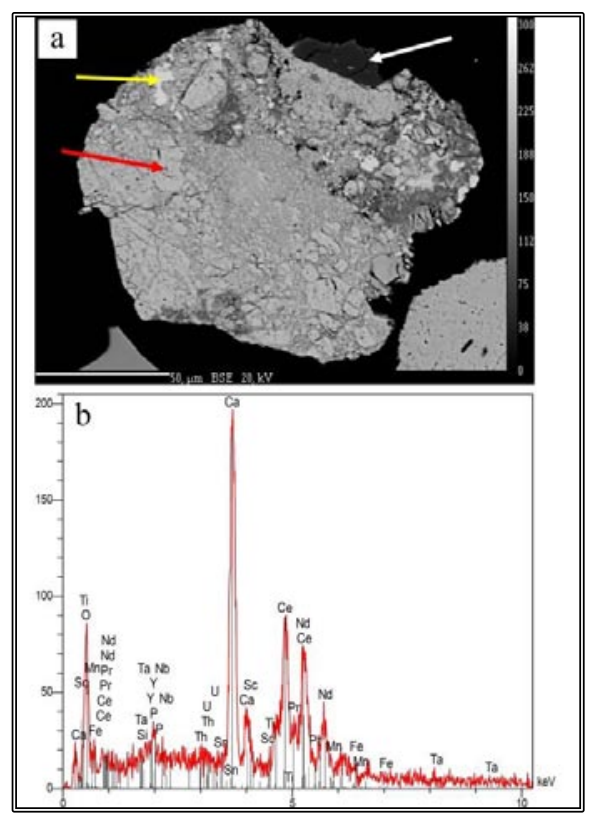


bearing thorite, and allanite, their concentrations decrease towards the downstream. These minerals may contain significant concentrations of $\mathrm{U}$ and Th. Thorite,yttrialite and thortveitite. In addition to several Nb-Ta-bearing phases. Radioactive biotite is present in some samples. The electron microprobe and EDX analyses constrain on the variable contents of Th and $\mathrm{U}$ in most heavy minerals under investigation. Considering the proximal radiometric anomalies and similar mineralogical composition of the Kab-Amiri intrusions and the more significant episyenite mass, it is clear that the investigated stream sediments are endogenic sediments with inherited radiogenic and mineral budget.

\section{REFERENCES}

Abdel Meguid, A. A., Ammar, S. E., Ibrahim, T. M. M., Ali, K. G., Shahin, H. A., Omer, S. A., Gaafar, I. M. E., Masoud, S. M., Khamis, A. A., Haridy, M. H., Kamel, A. I., Mostafa, B. M., Abo Donia, A., Abdel Gawad, A. E., and Aly, E. M., (2003): Uranium potential of Eastern Desert granites, Egypt. NMA internal report for project: EGY/03/014 technical Assistance by IAEA $270 \mathrm{p}$.

Ali, K. G., Gaafar, I. M., and Ibrahim, T. M. M., (2008): Structural control and geophysical signature of KabAmiriepisyenitized muscovite granite and associated uranium showings, Central Eastern Desert, Egypt. Ann. Geol. Surv., Egypt. Vol. 30, pp. 21-41.

Ammar, S.E.S., (1993): Geological, structural, and geochemical investigations of KabAmiri-Wadi El Saqia Area and its radioactive occurrences, Central Eastern, Desert, Egypt. PhD Thesis, Faculty of Science, Cairo University, Egypt, pp. 235- 236.

Bau, M. (1996): Controls on the fractionation of isovalent trace elementsin magmatic and aqueous systems: evidence from $\mathrm{Y} / \mathrm{Ho}, \mathrm{Zr} / \mathrm{Hf}$, andlanthanide tetrad effect. Contributions to Mineralogy and Petrology,123: 323-333.
Dill, H., (2010):The 'chessboard' classification scheme of mineral deposits: Mineralogy and geology fromaluminium to zirconiumEarth-Science Reviews, 100: 1-420

El Kassas, I.A., (1974): Radioactivity and geology of wadiAtalla area, Eastern Desert of Egypt, A.R.E., Ph.D. thesis, Ain Shams Univ., Cairo, Egypt.

Flinter, B. H., (1955): A magnetic separation of some alluvial minerals in Malaya, Amer. Miner., Vol. 44, No. 7-8, pp. 738-751.

Folk, R. L., (1954): The distribution between grain size and mineral composition in sedimentary rock nomenclature. J. Geol., Vol. 62, pp. 344-359.

Folk, R. L., (1980): Petrology of sedimentary rocks. Univ. Texas, Hemphill, Pup. Co., Austin, Texas, USA.

Gaafar, I, M., Ali, K. G., and Kandil, K. M., (2010): Ground geophysical survey and radon detection of WadiKabAmiri, Central Eastern Desert, Egypt. 18 P.

Hassaan, A. H. A., (2005): Evaluation of the heavy minerals in the coastal sand dunes, East Sabkhit Al-Tinna, North Sinai, Egypt. Ph. D. thesis, Fac., of Sci., Ain Shams Univ.

Hayashi, M., (1973): Hydrothermal alteration in the Otake geothermal area, Kyushu, Japan geothermal Association, 10: 1-46.

Leroy, S., (1978): The Margnac and Fanay uranium deposites of the La Crouzille District (Western Massif Central, France): Geologic and fluid inclusion studies. Economic geology. 73: 1611-1634.

Orris, G.J., and Grauch, R.I., (2002): Rare Earth Element Mines,Deposits, and Occurrences. Open-File Report 02-189. Reston,VA: USGS.

Phillips, W. R. and Griffen, D. T., (1981): Optical mineralogy, the non opaque minerals. Freeman and Company, Sanfrancisco. U.S.A.

Wark, D.A. and Miller, C.F. (1993):Accessory mineral behavior duringdifferentiation of a granite suite: monazite, xenotime, and zircon in theSweetwater Wash pluton, southeastern California, U.S.A. Chemical Geology, 110: 49-67. 